\title{
COMMENT
}

\section{THE CONSTITUTIONALITY OF QUALIFYING FEES FOR POLITICAL CANDIDATES}

The validity of qualifying fees, the nonpayment of which bars a candidate from placement on a state primary or general election ballot or totally from running for public office, has passed into a new context of judicial scrutiny. The early state decisions involving challenges to qualifying fees, ${ }^{1}$ and an occasional case in more recent years, ${ }^{2}$ turned for the most part on the integrity of the fee scheme under the enabling provisions of the state constitution and the reasonableness of the fee. ${ }^{3}$ Such schemes were often upheld. ${ }^{4}$

Although particular fee schemes may be both authorized by and reasonable under state constitutions, broader considerations suggest that these requirements may be impermissible within our scheme of government. Because fee schemes burden interests protected by the Constitution while classifying candidates and voters by means of a monetary exaction, the fourteenth amendment requires more than cursory examination of the states' reasons for using such mechanisms to determine whether their use effects a denial of the equal protection of the laws guaranteed by that amendment.

Within the past two years the lower federal courts have faced a number of cases challenging various fee schemes on equal protection grounds. The resulting split in decision of seven recent district court

1 Challenges were made to both qualifying fees and other aspects of primary laws soon after their passage. See, e.g., Socialist Party v. Uhl, $155 \mathrm{Cal} .776,103$ P. 181 (1909); People ex rel. Breckon v. Board of Election Comm'rs, 221 IIl. 9, 77 N.E. 321 (1906) ; Kelso v. Cook, 184 Ind. 173, 110 N.E. 987 (1916) ; Kenneweg v. County Comm'rs, 102 Md. 119, 62 A. 249 (1905); State ex rel. Adair v. Drexel, 74 Neb. 776,105 N.W. 174 (1905); Ballinger v. McLaughlin, 22 S.D. 206, 116 N.W. 70 (1908); Ledgerwood v. Pitts, 122 Tenn. 570, 125 S.W. 1036 (1910).

2 Bodner v. Gray, 129 So. 2d 419 (Fla. 1961); Munsell v. Hennegan, 182 Md. 15,31 A.2d 640 (1943); McLean v. Durham County Bd. of Elections, 222 N.C. 6 , 21 S.E.2d 842 (1942).

3 See, e.g., McLean v. County Bd. of Elections, 22 N.C. 6, 10, 21 S.E.2d 842, 845 (1942), in which the court concluded:

It is only one of the reasonable means adopted by the Legislature to regulate primary elections .... and to prevent an indiscriminate scramble for office and the wholesale filing of petitions for nomination regardless of fitness or qualification.

Id. The court did not discuss the relationship between the payment of a fee and "fitness or qualification."

4 See, e.g. Socialist Party v. Uh1, 155 Cal. 776, 103 P. 181 (1909); State ex rel. Thompson v. Scott, 99 Minn. 145, 108 N.W. 828 (1906). Contra, Johnson v. County of Grand Forks, 16 N.D. 363, 113 N.W. 1071 (1907). 
determinations ${ }^{5}$ and pending Supreme Court review of one ${ }^{6}$ indicate the need for analyzing this monetary method of election regulation.

Of the three district court decisions that upheld the qualifying fee schemes recently attacked-Fowler $v$. Adams, ${ }^{7}$ Spillers $v$. Slaughter, ${ }^{8}$ and Wetherington v. Adams ${ }^{3}$-the Wetherington decision is representative. The plaintiff was a prospective candidate seeking nomination to the Florida Legislature in a primary election for which appearance on the ballot was conditioned upon the payment of a $\$ 300$ fee. Wetherington's argument that the amount of the fee, because of his "lack of wealth," contravened his constitutional rights was rejected with the broad language that "as a matter of law . . . the size of the fee is not such as to raise any constitutional question of intentional or purposeful discrimination, or of unreasonableness . . . ."10

On the issue whether the exaction of any such filing fee was unconstitutional, the court considered and rejected Wetherington's due process and equal protection arguments. Although rather summarily dismissing the due process contention, ${ }^{11}$ the court analyzed the equal protection question rather carefully, determining the purposes of the fee requirement, the interests protected by the state, and the interests of those disadvantaged by the fee requirement. The court found the purposes of the law to be three: "to insure serious political candidates;" to limit the number of candidates as an accommodation to the "machinery set up by the Legislature for the purpose of electing its public officials;" and "to provide support, in a monetary form, to political parties so as to encourage and strengthen them." 12 Concluding that these purposes involved legitimate state interests to which the fee requirement was "reasonably and rationally related," ${ }^{13}$ and that because of a statutory write-in provision "an indigent candidate is not dis-

5 Upholding the fees: Spillers v. Slaughter, 325 F. Supp. 550 (M.D. Fla.), motion for leave to file pet. for writ of mandamus denied, 402 U.S. 971 (1971); Fowler v. Adams, 315 F. Supp. 592 (M.D. Fla. 1970), appeal dismissed, 400 U.S. 986 (1971); Wetherington v. Adams, 309 F. Supp. 318 (N.D. Fla. 1970).

Overturning the fees: Carter v. Dies, 321 F. Supp. 1358 (N.D. Tex. 1970), prob. juris. noted, 403 U.S. 904 (1971); Thomas v. Mims, 317 F. Supp. 179 (S.D. Ala. 1970); Georgia Soc. Workers Party v. Fortson, 315 F. Supp. 1035 (N.D. Ga. 1970), aff'd on other grounds sub nom. Jenness v. Fortson, 403 U.S. 431 (1971); Jenness v. Little, 306 F. Supp. 925 (N.D. Ga. 1969), appeal dismissed as moot sub nom. Matthews v. Little, 397 U.S. 94 (1970). Of the 7, all except Thomas were decided by 3 -judge courts.

The trend appears to be toward overturning the fees, as exemplified by the recent case, not yet officially reported, Socialist Workers Party v. Welch, 40 U.S.L.W. 2275 (S.D. Tex. Oct. 27, 1971).

${ }^{6}$ Carter v. Dies, 321 F. Supp. 1358 (N.D. Tex. 1971), prob. jutris. noted, 403 U.S. 904 (1971).

7315 F. Supp. 592 (M.D. Fla. 1970) (3-judge court).

8325 F. Supp. 550 (M.D. Fla. 1971) (3-judge court).

9309 F. Supp. 318 (N.D. Fla. 1970) (3-judge court).

$10 I d$. at 320 .

$11 I d$.

$12 I d$. at 321.

$13 I d$. at 322 . 
criminated against unduly," 14 the court held that the fees did not contravene the equal protection clause.

The four cases that struck down the fees covered the gamut of political contests. Jenness $v$. Little ${ }^{15}$ and Thomas $v$. Mims ${ }^{16}$ involved fees required of candidates in a general election for municipal office; Carter $v$. Dies ${ }^{17}$ involved a primary for county office; and Georgia Socialist Workers Party v. Fortson ${ }^{18}$ involved a fee requirement for independent and "third party" candidates in a general election for governor and United States Representative. While the other cases invalidated fees for indigent candidates, Carter went further and struck down the fees for candidates without a showing of indigency if the fee was an "absolute qualification" for placement on the ballot, or if the fee was used as a "revenue collecting device." 19

Carter nevertheless illustrates the kind of approach taken in these four cases. ${ }^{20}$ The fees under attack were required of candidates in primary elections under a Texas statute authorizing county committees to apportion election costs among the candidates. Without attempting to distinguish the $W$ etherington decision in any meaningful way, ${ }^{21}$ and refusing to hold that a state could never require a fee, ${ }^{22}$ the court struck down the fees. Reasoning that this fee scheme encumbered both the fourteenth amendment right "to choose one's candidate" and the first amendment right of political association, ${ }^{23}$ the court demanded that the state show a "compelling state interest" to justify its fee scheme. Rejecting as insufficiently compelling the purpose of raising revenue, ${ }^{24}$ the

$14 I d$. at 321,322 . It is not entirely clear that the court was correct in thinking that Florida's write-in provision applies to primary elections. Act of June 1, 1967, ch. 142, \$1, [1967] Fla. Laws 281 (emphasis added), in force at the time suit was filed, provided:

(1) Any person seeking election by write-in votes ... shall have, not less

than thirty days prior to the general election, certified ... the following information....

...

(3) The department of state shall, not less than twenty days before said genteral election, certify the names of such write-in candidates.. On July 3,1969 , the dates for certification were changed from 30 to $20 \dot{0}$ days before the general election to 45 and 30 days before, respectively. See FLA. StAT. ANN. $\$ 99.023$ (Supp. 1971).

15306 F. Supp. 925 (N.D. Ga. 1969) (3-judge court), appeal dismissed as moot sub noni. Matthews v. Little, 397 U.S. 94 (1970).

16317 F. Supp. 179 (S.D. Ala. 1970).

17321 F. Supp. 1358 (N.D. Tex. 1970) (3-judge court).

18315 F. Supp. 1035 (N.D. Ga. 1970) (3-judge court).

$19321 \mathrm{~F}$. Supp. at 1362.

20 The 4 cases striking down qualifying fees, of course, manifest differing degrees of analytic effort. Carter's particularly broad exposition is useful in illustrating the vast difference in approach between these cases and Wetherington.

21 See 321 F. Supp. at 1362-63.

22 Id. at 1362.

23 Id. at 1361.

$24 \mathrm{Id}$. 
court quoted from Harper v. Virginia State Board of Elections ${ }^{25}$ broad language prohibiting state efforts to make the "payment of any fee an electoral standard," 26 and concluded that the fee requirement was unconstitutional. ${ }^{27}$

This Comment analyzes recent Supreme Court cases delineating, in the voting context, those interests protected by the Constitution, examines various kinds of qualifying fee schemes currently employed by the states, and suggests that under proper constitutional analysis all fee schemes must fall.

\section{Formulas and Equal Protection}

It has long been recognized that legislation by its very nature classifies. ${ }^{28}$ At the same time, the fourteenth amendment's equal protection clause demands "the protection of equal laws." 29 Courts, faced with equal protection challenges to state action, have reconciled this fourteenth amendment requirement with their recognition of the nature of legislation by demanding that those similarly situated be similarly treated. ${ }^{30}$

Any candidate qualification requirement by its very nature erects a -classification ${ }^{31}$ by which the state either permits or denies prospective candidates access to either public office or a particular channel to public office. $^{32}$ Moreover, even if everyone must meet the same requirement in order to run for office or to enter a certain channel, depending upon the particular mechanism and the criterion for classification it has chosen, the state will exclude or disadvantage different groups. Unlike

25383 U.S. 663, 666 (1966).

26321 F. Supp. at 1362 .

27 Id.

28 See Tussman \& tenBroek, The Equal Protection of the Lazus, 37 CadrF. I. REv. 341, 343-44 (1949).

29 Id. 344.

30 Tigner v. Texas, 310 U.S. 141, 147 (1940).

31 For a general discussion of classification, see Tussman \& tenBroek, supra note 28 , at 344-45. While qualifying fee schemes do not expressly prohibit indigents from becoming candidates, in effect, because the exercise of rights of candidacy is conditioned on a monetary payment, the classification is quite similar to an express prohibition. See Note, Discriminations Against the Poor and the Fourteenth Amendment, 81 HARV. L. REv. 435, 437 (1967). Although all qualifying fee schemes employ the same criterion for classifying-payment of a fee-the mechanisms in use vary. As will be seen, paying the fee may determine whether the candidate may run at all, whether he may only run as a write-in candidate, whether he receives name placement on the ballot, and whether he may enter a primary.

32 For the purpose of this analysis, a requirement denies access to public office when those who do not meet it may not run for office at all. Thus, it is, in effect, a requirement for holding office. Some qualification requirements, on the other hand, only apply to particular routes to office. Thus, a fee or a nominating petition requirement might be imposed only upon those who enter political primaries or only upon independents who desire to have their name placed on the general ballot. Write-in candidacy is another route to public office that may be burdened by a qualification requirement. 
the qualification mechanisms required by some states, ${ }^{33}$ fee schemes adversely affect those candidates who cannot afford to pay the fee and those who, despite their ability to pay, are deterred by the fee from entering the political arena. They are effectively denied an opportunity that, although offered by the state to all on equal terms, is more difficult for them than for others, or even impossible for them, to obtain. As a consequence of requiring fees of prospective candidates, qualifying fee schemes also classify certain groups of voters: voters who actually prefer a particular candidate who has qualified and those who would prefer a particular candidate who has not.

The degree to which candidates and voters are adversely affected by a fee requirement, however, depends upon the nature of the fee mechanism a state uses. Some fee schemes permit only those who have paid a fee to run for office. On the other hand, some qualifying fee schemes supply a write-in space and, thus, do not completely deny candidates the chance to run for office and voters the chance to indicate their preference. ${ }^{34}$ Whether either or both of these arrangements meet minimum constitutional standards may depend on the degree to which the former restricts the voter's opportunity effectively to choose a candidate reasonably reflecting the voter's political views or on the acceptability of such total candidate disqualification, and, if on either basis total exclusion is unacceptable, the degree to which the latter restricts the candidate's chance to try to win and the voter's opportunity to vote for a candidate who could, with his name printed on the ballot, expect substantially more support from other voters.

In addition, many fee schemes, by requiring fees for party primaries, also distinguish between those candidates who may qualify for name placement on the general election ballot. Thus, some candidates by paying the primary fee will have the chance to win a party label that they can carry onto the general election ballot with them. This classification also affects voters, since some will have the chance to vote for a candidate identified with a particular group while others will not. State qualifying procedures commonly relegate the nonparty candidates and their supporters either to an alternative qualification procedure under which the candidate will appear on the ballot without party identification as an independent if he qualifies, or to either use of a write-in space or exclusion from the election. ${ }^{35}$ Under the nonparty routes to office the candidate may still face some form of fee requirement, and the analysis of voter and candidate classification presented above may still be applicable. In sum, prospective candidates are typically classified by statute into four groups-party candidates, inde-

33 Nominating petition requirements, used exclusively by 15 states, and to some extent by 47 states, may deny access either to the office or to a particular route to office; such denial is, however, based on the candidate's lack of support as evidenced by his inability to gather signatures. See text following note 103 infra.

34 See Appendix infra.

35 See id. 
pendent candidates, write-in candidates, and those totally excluded. Fee schemes are used in a number of states to effect these classifications.

In deciding whether state action unconstitutionally classifies, the Supreme Court has articulated two essentially distinct tests for deciding equal protection claims. ${ }^{36}$ The traditional test requires upholding state action in the face of equal protection attack if any "reasonable basis" for the classification exists to achieve a legitimate state goal..$^{37}$ If, however, the state action affects some "fundamental right" 38 - either a constitutional right ${ }^{39}$ or some other "basic civil right of man" ${ }^{40}$-or if the classification is based upon "suspect" criteria," the Court will "carefully and meticulously" scrutinize ${ }^{22}$ the state action in search of the requisite "compelling governmental interests." 43 In the absence of such a compelling interest, the state action must fall.

These equal protection formulas, of course, do not automatically provide an answer to the question whether a given state action is constitutional. ${ }^{44}$ On the other hand, they are more than mere terminology with which the Court can frame its conclusion. They provide a convenient framework within which to focus upon, isolate, and analyze various important factors of a particular legislative scheme.

This framework is, unfortunately, too convenient, as is also the sometimes useful characterization of the test as a sliding twodimensional scale. ${ }^{45}$ In its simplicity it provides temptation to subject

36 See, e.g., Cipriano v. City of Houma, 395 U.S. 701 (1969) (per curiam); Shapiro v. Thompson, 394 U.S. 618 (1969); Developments in the Law-Equal Protection, 82 HaRv. L. REv. 1065 (1969).

37 See Dandridge v. Williams, 397 U.S. 471, 485 (1970) ; Gulf, C. \& S.F. Ry. v. Ellis, 165 U.S. 150, 155 (1897). For an articulation of this extremely permissive approach, see McDonald v. Board of Election Comm'rs, 394 U.S. 802, 809 (1969):

Legislatures are presumed to have acted constitutionally even if source materials normally resorted to for ascertaining their grounds for action are otherwise silent, and their statutory classifications will be set aside only if no grounds can be conceived to justify them.

38 Shapiro v. Thompson, 394 U.S. 618, 638 (1969).

39 See Williams v. Rhodes, 393 U.S. 23 (1968).

40 Skinner v. Oklahoma ex rel. Williamson, 316 U.S. 535, 541 (1942).

41 See, e.g., Korematsu v. United States, 323 U.S. 214, 216 (1944) (dictum).

42 Reynolds v. Sims, 377 U.S. 533, 562 (1964).

43 Shapiro v. Thompson, 394 U.S. 618, 634 (1969).

44 It should be noted, however, that under the "rational relation" test as it has generally been applied in economic regulation, qualifying fee schemes would probably be held constitutional. To some extent this traditional test depends upon the purpose that the state claims its legislation was designed to achieve. If the statute's purpose is to insure serious or well-supported candidates, rather than to raise money, the classification will be both underinclusive and overinclusive, since many who can pay will not be well-supported, while many who cannot pay will be well-supported. Whether the classification, given such a purpose, will fall depends on a variety of factors. See Tussman \& tenBroek, supra note 28, at 347-53.

On the other hand, if the purpose of a particular qualifying fee is to raise money, the rational relation test is clearly met. Cf. note 37 supra. The question remains, however, whether such a classification is constitutional in view of the nature of the rights involved. Analyzing this second question, this Comment assumes that qualifying fees do pass the usual rational relation test.

45 See Developments in the Laze-Equal Protection, supra note 36, at 1120-21. 
to rigid classification a multitude of problems requiring variegated solutions. Indeed, precisely in the area of voting rights and the operation of election machinery this framework now shows signs of crumbling. Perhaps the most articulate formulation given this fact by a member of the Court came from Justice Marshall, who supported his formulation, albeit in a welfare case dissent, with citations to two of the major cases in the voting rights area:

In my view, equal protection analysis of this case is not appreciably advanced by the a priori definition of a "right," fundamental or otherwise. Rather, concentration must be placed upon the character of the classification in question, the relative importance to individuals in the class discriminated against of the governmental benefits that they do not receive, and the asserted state interests in support of the classification. As we said only recently, "In determining whether or not a state law violates the Equal Protection Clause, we must consider the facts and circumstances behind the law, the interests which the State claims to be protecting, and the interests of those who are disadvantaged by the classification." Kramer v. Union School District, 395 U.S. 621, 626 (1969), quoting Williams v. Rhodes, 393 U.S. 23, 30 (1968). ${ }^{46}$

To this analysis other factors worthy of weight might be added. For present purposes it suffices to point out that the interests of a class may be "fundamental" because they are, or further, interests that our system of government should foster for its own good. A court evaluating equal protection claims should engage in a visible balancing of interests, very carefully evaluating the importance of each interest. This should ensure the best possible result and the exclusion of frequently overlapping subjective elements of decision.

Parsing the elements worthy of concern in testing the constitutionality of qualifying fees, this Comment will focus upon those factors that merit weight in such an analysis either because the Court has accorded them weight in recent opinions or because they appear particularly significant in terms of the political realities of American democracy.

The following section will trace the Court's recent decisions involving candidates, voting, and political parties, and will attempt to identify the interests the Court has perceived as particularly worthy of protection under the equal protection clause. The final section will examine the common state qualifying schemes incorporating fee requirements and apply the lessons of the decisional analysis to the structure and realities of those schemes when viewed against the background of the alternatives available to serve the legitimate ends states seek to achieve.

46 Dandridge v. Williams, 397 U.S. 471, 520-21 (1970) (footnotes omitted). 
II. Candidates, Voters, and Political Parties: The Identification of Protected Interests

\section{A. Protecting Candidates for Elective Office}

Although the Supreme Court has never recognized a constitutional right to be considered for elective public office and has left to the states the determination whether a particular office will be appointive or elective, once that determination has been made, the Court has held that in being considered for that office an individual is entitled to the equal protection of the law. In Turner $v$. Fouche ${ }^{47}$ the Court struck down a Georgia law limiting appointive school board membership to freeholders as a violation of the fourteenth amendment. It found it unnecessary to decide whether a compelling state interest must be shown to justify restrictions on qualification for office. ${ }^{48}$ But as to the freeholder requirement, the Court expressly rejected any claim that a citizen "must . . . own real property if he is to participate responsibly in education decisions" ${ }^{49}$ and added that lack of ownership does not establish "a lack of attachment to the community and its educational values." 50 Despite the Court's assertion that "it seems impossible to discern any interest the qualification can serve," 51 its rationale imposes a far more stringent test than a requirement that a state's action have some conceivable rational relation to a legitimate end it seeks. Turner makes clear that the rational relationship needed to justify restricting consideration for public office, while perhaps not the same as the "compelling state interest" sometimes required for legislative classifications, is something quite different from the rational relationship that the Court will accept when less important interests are involved. ${ }^{52}$ At the least, Turner demonstrates that when consideration for public office is

47396 U.S. 346 (1970).

$48 \mathrm{Id}$. at 362.

49 Id. at 363-64.

$50 I d$. at 364 (emphasis added).

$51 \mathrm{Id}$. at 363. Georgia, apparently attempting to show that its freeholder requirement was rationally related to several state goals, urged (1) that ownership of real estate leads to responsible participation in educational decisions, and (2) that "the lack of ownership of realty establish [es] a lack of attachment to the community and its educational values." Id. at 363-64. Similarly, Justice Harlan attempted in his Harper dissent to demonstrate a rational relationship between voting and the poil tax:

[I] $t$ is certainly a rational argument that payment of some minimal poll tax promotes civic responsibility, weeding out those who do not care enough about public affairs to pay $\$ 1.50 \ldots$. It is also arguable . . . that people with some property have a deeper stake in community affairs, and are consequently more responsible, more educated, more knowledgeable, more worthy of confidence, than those without means . . . .

383 U.S. at $684-85$.

52 Cf. Dandridge v. Williams, 397 U.S. 471, $508-30$ (1970) (Marshall, J., dissenting). Compare, e.g. Turner v. Fouche, 396 U.S. 346 (1970); Harper v. Virginia Bd. of Elections, 383 U.S. 663 (1966); Carrington v. Rash, 380 U.S. 89 (1965); Skinner v. Oklahoma ex rel. Williamson, 316 U.S. 535 (1942); with, e.g., McGowan v. Maryland, 366 U.S. 420 (1961); Metropolis Theater Co. v. Chicago, 228 U.S. 61 (1913); Lindsley v. Natural Carbonic Gas Co., 220 U.S. 61 (1911). 
involved, the Court will not tolerate the evils of an overinclusive classification:

Whatever objectives Georgia seeks to obtain by its "freeholder" requirement must be secured, in this instance at least, by means more finely tailored to achieve the desired goal. ${ }^{53}$

Although Turner spoke in the context of an appointive office, its holding must be carefully examined if lessons for the protection of candidates for elective office are to be sought. The Court's words were:

[T] he appellants and the members of their class do have a federal constitutional right to be considered for public service without the burden of invidiously discriminatory disqualifications. The State may not deny to some the privilege of holding public office that it extends to others on the basis of distinctions that violate federal constitutional guarantees. ${ }^{54}$

Thus, under Turner, a state qualification scheme that imposes upon every channel to an elective office a condition lacking some substantial justification will fail to satisfy the requirements of the fourteenth amendment simply because it effects an invidious discrimination among candidates. In such a case the state has made failure to meet the condition a disqualification from holding public office.

When, however, the state has left one channel to office, among several, free of the forbidden requirement, the problem becomes more complicated-and this may be true no matter how meager that channel is. In such a case, the state has made the fee not a requirement for holding office, but a requirement for a particular way of running for that office. One might attempt to extrapolate from Turner the suggestion that because the state classifies candidates, once they are given the chance to run, into party candidates, independent candidates, and write-in candidates, it must make that classification as well upon grounds unrelated to payment of a fee unless it can show sufficient justification under the Turner approach. This attempt, however, assumes too much.

The candidate may, when others are given the chance to garner votes at a general election, only have a right to the same opportunity through a procedure "more finely tailored" to office qualification than is a fee scheme. But if he wishes more than this minimal opportunity, limits on the state's power to impose restrictions, including fee require-

53396 U.S. at 364 . The similarity between a fee requirement and a freeholder requirement consists in their overinclusive and underinclusive elements. See note 100 infra. When important interests are adversely affected, the state should be required to choose a "more finely tailored" criterion, assuming it may constitutionally classify at all. Cf. Socialist Workers Party v. Welch, 40 U.S.L.W. 2275 (S.D. Tex. Oct. 27, 1971).

54 Id. at 362-63 (footnotes omitted) (emphasis added). 
ments, limiting that opportunity, are less clear. It does not follow from Turner that because the state has failed to justify a fee for allowing a candidate any access to the electorate, it cannot justify by a lesser showing the requirement that the candidate pay a fee for the additional opportunity to attempt to have his name, or both his name and that of an endorsing political party, printed on the ballot. In other words, Turner may stand for no more than the principle that a state may not distribute the chance to run for office on the basis of wealth.

Thus, in the context of elective office, should a court feel that, by providing one channel through which candidates may qualify to garner votes at a general election free of unconstitutionally discriminatory conditions, the state has left unburdened the only right worthy of the rather strong protection accorded by the Supreme Court in Turnerthat is, the right to be considered for public office on a nondiscriminatory basis-even a write-in space might be sufficient to satisfy the constitutional mandate.

Such a holding would be shortsighted. The intricacies of the American electoral system are quite different from the mechanics of an appointive system. And the usual state political process is lacking in simplicity and openness, a fact courts should take into account. As we shall see, the interests to be protected, when voting, rather than appointment, determines the officeholder, extend beyond those of the candidate, and state election machinery typically provides more than one way to gain access to the electorate. The Supreme Court has protected these other interests as well, and protected them assiduously. Thus, before examining the intricacies of state election machinery to determine whether fee schemes meet the requirements of the fourteenth amendment, it is necessary to examine those opinions to determine the fundamental interests they protect, and to explicate the efforts to which the Court is prepared to put the states in respecting those interests.

\section{B. Protecting the Right to Vote}

The requirement that a person pay either for a benefit supplied by the state or for permission from the state to engage in certain activity is, of itself, rather commonplace. Requiring payments for the privileges of operating a liquor store or driving a car on the state's highways does not, without more, require more justification than a showing that the particular requirement bears a rational relationship to some legitimate state interest.

In the voting context, however, the Supreme Court has explicitly forbidden the states from placing a price on the exercise of the franchise. In Harper v. Virginia State Board of Elections, ${ }^{55}$ the Court found that a general poll tax of at most $\$ 1.50$, combined with the sanction of disenfranchisement for failure to pay, created a classification whereby "the affluence of the voter or payment of any fee" became "an electoral 
standard," 56 and held this requirement "invidious discrimination" contravening the equal protection clause. Refusing to discuss in depth the constitutional basis for the "right to vote" in state elections or the nature of the state's power to restrict the franchise, the Court ruled that

once the franchise is granted to the electorate, lines may not be drawn which are inconsistent with the Equal Protection Clause of the Fourteenth Amendment. ${ }^{57}$

With respect to the principle or formula that the Court used in striking down the poll tax, Harper has been called a "symphony of holdings." 58 At one point in the opinion the Court seems to say that the poll tax has no rational relation to any legitimate state goal: "Voter qualifications have no relation to wealth nor to paying or not paying this or any other tax." 59 Yet at the end of the opinion, this approach becomes mixed with another theory:

We have long been mindful that where fundamental rights and liberties are asserted under the Equal Protection Clause, classifications which might invade or restrain them must be closely scrutinized and carefully confined. . . .

Those principles apply here. For to repeat, wealth or fee paying has, in our view, no relation to voting qualifications; the right to vote is too precious, too fundamental to be so burdened or conditioned. ${ }^{60}$

In light of both the ease with which Justice Harlan in dissent established that "arguments have been and still can be made in favor of" property qualifications ${ }^{61}$ and discussions of the Harper principle in later Court decisions, ${ }^{62}$ the case obviously stands for more than the principle that poll taxes have no rational basis. Instead, besides reflecting the Court's concern that the poor not be denied the access to the vote available to the rich, Harper must be taken at its word that such wealth classifications "must be closely scrutinized and carefully confined." 63

Far from being an unprecedented holding, this proscription merely began to give voice to the broad intimations in Justice Stone's famous footnote four of United States v. Carolene Products Co.: ${ }^{\text {} 4}$

$56 I d$. at 666.

$57 I d$. at 665.

58 Michelman, On Protecting the Poor Through the Fourteenth Amendment, 83 HARV. L. REV. 7, 25 (1969).

59383 U.S. at 666.

$60 I d$. at 670 (citations omitted).

61 Id. at 684-85 (Harlan, J., dissenting); see note 51 supra.

62 See, e.g., McDonald v. Board of Election Comm'rs, 394 U.S. 802, 807 (1969).

63383 U.S. at 670.

64304 U.S. 144 (1938). 
It is unnecessary to consider now whether legislation which restricts those political processes which can ordinarily be expected to bring about repeal of undesirable legislation, is to be subjected to more exacting judicial scrutiny under the general prohibitions of the Fourteenth Amendment than are most other types of legislation. ${ }^{65}$

And, although the Court's opinion in Harper did not cite the Carolene Products footnote, it did quote language from Reynolds $v$. Sims, ${ }^{68}$ a reapportionment case, to the same effect:

Undoubtedly, the right of suffrage is a fundamental matter in a free and democratic society. Especially since the right to exercise the franchise in a free and unimpaired manner is preservative of other basic civil and political rights, any alleged infringement of the right of citizens to vote must be carefully and meticuously scrutinized. ${ }^{67}$

Harper thus recognized that one man's vote is important primarily because it is part of a political force with the potential power to determine the legislative policies governing his life. Thus viewed, Harper banned the poll tax because it disenfranchised a class of citizens by means of a monetary exaction and so rendered that class powerless to remove, by voting, the very restriction that disenfranchised them. This is not to say that one man's vote of itself is unimportant. True, the right to vote in many ways is an individual right fortifying the dignity of a citizen and bolstering his sense of political participation. The importance of one man's vote, however, lies primarily in its potential for combining with that of others to effect change.

While only indigents are clearly excluded by a poll tax they cannot afford to pay, Harper struck down the tax for all residents, those who could afford to pay as well as those who could not. ${ }^{68}$ The Court, thus,

65 Id. at 152 n.4. This same notion and the Supreme Court's resolution of the general problem were well stated recently in Kramer v. Union Free School Dist., 395 U.S. 621 (1969) :

The presumption of constitutionality and the approval given "rational" classifications in other types of enactments are based on an assumption that the institutions of state government are structured so as to represent fairly all the people. However, when the challenge to the statute is in effect a challenge of this basic assumption, the assumption can no longer serve as the basis for presuming constitutionality.

Id. at 628 (footnotes omitted).

66377 U.S. 533 (1964).

67383 U.S. at 667 (quoting Reynolds v. Sims, 377 U.S. 533, 561-62 (1964)).

68 Both the outlines of this larger injured class and the general principle by which it was protected are, perhaps, more clear if the poll tax is hypothetically set at $\$ 50$ instead of $\$ 1.50$. Thus, the "injured" class includes not only indigents but also those voters able to pay the $\$ 50$ fee who are, nevertheless, deterred from voting by the tax alone. While often such a tax provides only an excuse to an already disinterested voter, many of these deterred voters would fail to vote because, upon measuring the "present value" of their vote, so to speak, in terms of its power to 
decided that the poll tax places an impermissible burden even upon those voters to whom the tax itself was insignificant. If one would look for a reason he might do worse than to return to the Carolene Products rationale. Such a tax does not merely skew the class of voters toward the more wealthy-it invites each voter to weigh the value of his vote, and, if he is human, he is likely to weigh it in terms of its return to him, failing to consider or, at least undervaluing, the importance to society of an open political system responsive to his and others' wishes.

To be sure, Harper on its facts speaks only to state action that conditions upon the payment of a fee the casting of one's vote in any manner, just as Turner speaks to the opportunity to be considered for public office in any manner. The decision does not compel a result in the case of a qualifying fee scheme in which a voter is free to proceed to the voting booth and cast his ballot, but finds that his candidate has been either disqualified from running or relegated to write-in or independent status that will make it difficult or impossible for that candidate to attract a concentration of votes sufficient to gain office and for the voter to vote for or help to elect him. Going a step further, while a state may not require a citizen to pay for his vote, it does not necessarily follow from this that a state may not, consistent with the equal protection clause, require candidates to pay for their places on the ballot.

But although Harper does not reach the relationship between the right to vote and the opportunity to have the candidate of one's choice appear on the ballot, clearly the right to vote in any manner, guaranteed against monetary disincentives by Harper, means little in practical terms if it does not include the possibility of voting with some effect. One must assume that the Court was aware that to fulfill its purpose the right to vote, when given by the state at all, must guarantee more than merely the right to cast a ballot.

\section{The Nexus Between Voting and Candidacy}

Williams v. Rhodes," decided two years after Harper in a "hastily reached, divided, and potentially far-reaching decision," 70 provides clues to the proper relationship between the protections afforded the

effect desirable change, against the $\$ 50$ tax, they would find in the $\$ 50$ saved a greater benefit. Such a person will simply not waste his money voting. Further, if many people similarly situated perform the same calculus of balancing marginal utilities, they will all refrain from voting, even if, in fact, collectively they could have changed the result of the election. Because of imperfect information, people simply do not realize how important in practical terms their vote really is.

Thus, upon this analysis, the Court in Harper realized that because one man's vote is valuable in terms of power only when combined with the votes of others of similar persuasion, any voter tends to "undervalue" the worth of his vote. The Court apparently did not want this voter to engage in a utilitarian calculus with his vote.

69393 U.S. 23 (1968).

70 G. Gunther \& N. Dowling, Cases and Materials on Constitutronal Law 1016 (8th ed. 1970); see Williams v. Rhodes, 393 U.S. 23, 63-70 (1968) (Warren, C.J., dissenting). 
right to vote in Harper and state restrictions on candidacy. The restraints attacked in Williams were not qualifying fees, but the intricate mechanism by which Ohio through its election laws

made it virtually impossible for a new political party, even though it has hundreds of thousands of members, or an old party, which has a very small number of members, to be placed on the state ballot [for presidential electors]. ${ }^{71}$

Under Ohio law, in presidential elections, political party conventions nominated slates of electors, rather than candidates, to appear on general election ballots. While electors could be selected only by political parties, voters voted for these electors at the general election rather than for the particular parties that had selected them. ${ }^{72}$ In addition, the state placed nearly insurmountable obstacles in front of political parties that had failed to poll at least ten percent of the votes cast in the previous gubernatorial election-in effect, all parties except the Democratic and the Republican. Finally, these disfavored parties were required not only to maintain an organization of substantial complexity, but also to collect by February of the election year a number of signatures equaling fifteen percent of the votes cast in the previous gubernatorial election. Failing to meet all of the requirements, a party's nominated electors were foreclosed from the ballot.

Rejecting the state's argument that under article II, section 1 of the Constitution the state had absolute power to put restraints on the selection of electors, ${ }^{73}$ the Court held that "no State can pass a law regulating elections that violates the Fourteenth Amendment's command . . . " $\tau^{4}$ The Court then concluded that Ohio's laws had that effect:

[T] he state laws place burdens on two different, although overlapping, kinds of rights-the right of individuals to associate for the advancement of political beliefs, and the right of qualified voters, regardless of their political persuasion, to cast their votes effectively. ${ }^{75}$

Requiring, but failing to discern, a "compelling interest," the Court struck down the restrictive election laws. ${ }^{76}$

71393 U.S. at 24.

72 Onto Rev. Cone AnN. $\$ 3513.11$ (Page 1960); see State ex rel. Beck v. Hummel, 150 Ohio 127, 80 N.E.2d 899 (1948).

73393 U.S. at $28-29$.

$74 I d$. at 29.

75 Id. at 30 .

76 Id. at 31 . The Court, modifying the district court's judgment ordering the state to provide write-in space for both parties, required the state to maintain on the ballot the name of the American Independent Party (AIP), placed there pursuant to an interlocutory order of Justice Stewart in his capacity as Circuit Justice. The Court, however, did not require the state to place the Socialist Labor Party's (SLP's) name on the ballot, because that party had not made timely application to Circuit Justice Stewart and because the Court felt that forcing the state to place the SLP on the ballot would disrupt the election process. Id. at 34-35. 
Williams is significant, first, because it recognized explicitly a right to vote "effectively" and required the state to show a compelling interest to justify its onerous scheme. The Ohio laws, like those in Harper, did not place a direct burden on the right to cast a ballot. Thus, voters could still go to the polling place and vote. But the Court recognized that the right to vote entails more than merely the chance to cast a ballot. To protect the right to vote, the Court perceived that it must restrict the power of the state to limit candidate access to the ballot on the basis of identification with a particular political association or group.

The right to form a party for the advancement of political goals means little if a party can be kept off the election ballot and thus denied an equal opportunity to win votes. So also, the right to vote is heavily burdened if that vote may be cast only for one of two parties at a time when other parties are clamoring for a place on the ballot. ${ }^{77}$

This rationale merely gives further effect to the principle of political openness that was the basis for Justice Stone's Carolene Products footnote and that served as the premise for, and was protected, at least to some extent, by Harper. Thus, Justice Stone intimated that restrictions on the political process should require greater justification than restrictions on less important interests, and Harper assumed that the vote, which it was protecting from monetary disincentives, was a right worth protecting. Williams, making Harper's premise true, made the right to vote worth something by translating it into a right to vote effectively.

Thus, in Williams the point had been passed beyond which a state's restriction of ballot placement makes virtually meaningless the right to vote and the right to associate. Williams does not say, however, that all restrictions on ballot placement are unconstitutional regardless of the particular makeup of the entire electoral procedure. In fact, recently in Jenness $v$. Fortson, ${ }^{78}$ involving an appeal from the Georgia Socialist Workers case, ${ }^{79}$ the Supreme Court upheld a nominating petition requirement that the state imposed only on independents and minor party nominees.

Under Georgia law, political organizations whose candidate received at least twenty percent of the vote at the previous gubernatorial or presidential election were guaranteed ballot placement for their primary winner. On the other hand, independents and nominees of organizations that had not previously polled twenty percent could gain

77 Id. at 31.

78403 U.S. 431 (1971).

79 Georgia Soc. Workers Party v. Fortson, 315 F. Supp. 1035 (N.D. Ga. 1970) (3-judge court). No appeal was taken from the district court's ruling that Georgia's filing fee requirement violated the equal protection clause. See Jenness v. Fortson, 403 U.S. 431, 432 (1971). 
ballot placement only by filing a nominating petition signed by at least five percent of those eligible to vote at the last election. Certain prospective candidates, registered voters, and political parties brought suit claiming violations of the first and fourteenth amendments. ${ }^{80}$

On the first amendment claim, the Court examined the electoral procedure as a whole and, distinguishing Williams, upheld Georgia's nominating petition scheme.

Unlike Ohio, Georgia freely provides for write-in votes. Unlike Ohio, Georgia does not require every candidate to be the nominee of a political party, but fully recognizes independent candidacies. Unlike Ohio, Georgia does not fix an unreasonably early filing deadline for candidates not endorsed by established parties. Unlike Ohio, Georgia does not impose upon a small party or a new party the Procrustean requirement of establishing elaborate primary election machinery. ${ }^{81}$

Thus, unlike Ohio, which had clearly burdened the right to associate, Georgia permitted the kind of openness under which small and new groups could easily form and flourish. "In a word, Georgia in no way freezes the status quo, but implicitly recognizes the potential fluidity of American political life." 82

The Court handled the equal protection claim on two levels. First, it held that requiring independents and minor party nominees to present a five percent nominating petition, while requiring a prospective major party candidate only to win the party primary, did not violate the equal protection clause, because neither of these routes to the ballot could be assumed to be "inherently more burdensome" than the other. ${ }^{83}$

On a different level, the Court faced the claim that Georgia violated the equal protection clause by guaranteeing to major parties, although to no particular candidate, a ballot position, while giving to minor parties, required to present a nominating petition, no such guarantee. $^{84}$ To this party, as opposed to candidate, claim, the Court answered only that

there are obvious differences in kind between the needs and potentials of a political party with historically established broad support, on the one hand, and a new or small political organization on the other. ${ }^{85}$

80 Although it had been one of the plaintiffs in the district court, the Georgia Socialist Workers Party was not an appellant. Nevertheless, the Court assumed that the individual appellants "can properly assert the interests of that "political body." 403 U.S. at 441 n.26.

$81 \mathrm{Id}$. at 438.

$82 I d$. at 439.

$83 I d$. at 441.

$84 I d$.

$85 I d$. 
Without analyzing these differences, the Court simply concluded that "[s] ometimes the grossest discrimination can lie in treating things that are different as though they were exactly alike . . . ." 86

While to some extent Jenness qualifies $W$ illiams by demonstrating that not all restrictions on ballot placement are unconstitutional, it does not question the basic holding of Williams that the right to vote effectively and freedom of association, in the voting context, are constitutionally protected interests. Although involving a repressive law $^{87}$ and highly visible classes of "injured" voters, ${ }^{88}$ in the thrust of the opinion, Williams is directly applicable to fee schemes, which also burden the right to vote effectively and the right to associate. Jenness only reveals that the constitutionality of burdens actually imposed on these rights depends a great deal on the nature of the state's election scheme as a whole.

Moreover, a qualifying fee scheme differs from a nominating petition requirement with respect to the classification it erects. Both requirements deny to some prospective candidates a place on the ballot. Thus, both limit the voter's choice. Qualifying fees, however, limit ballot placement to those who can afford its price, while the nominating petition provides ballot placement only to those who have demonstrated sufficient voter support. Since there is no indication that voters desire to choose only from among those who can afford to pay a fee and because it is reasonable to believe that some voters may desire to vote for those who cannot afford to pay the price, a fee requirement does not take into account the right to vote effectively. On the other hand, those who fail to obtain a sufficient number of signatures and thereby to demonstrate their support, can complain of little more than having been denied the opportunity to lose.

None of the four major cases discussed-Turner, Harper, Williams, and Jenness-provides an easy solution to the constitutionality of qualifying fee schemes. To a great extent, this is because there is no one fee scheme. Instead, the states employ various kinds of schemes, each of which may require a different analysis. Thus, some require the payment of a fee as an absolute condition for running for office, while others impose fees only upon candidates who have chosen a particular way to run. These cases do suggest, however, the considerations that any constitutional analysis of the problem must take into account.

$80 \mathrm{Id}$. at 442.

87 In Williams the election law was especially repressive. First, Ohio permitted the Republican and Democratic parties to reach the ballot, since each had polled at least $10 \%$ of the votes cast at the last election, but required third parties to file petitions with the signatures of $15 \%$ of the votes cast at the previous election. Williams v. Rhodes, 393 U.S. $23,25-26$ (1968). Secondly, the state eliminated independent candidacy, by requiring that nominees be endorsed by a political party, and abolished write-in votes entirely. Id. at 35-36 (separate opinion of Douglas, J.).

88 Both the AIP and the SLP were composed of yoters who had already taken the initial step of banding together with others of similar persuasion to form a recognizable political organization. 
Turner suggests requiring a state to demonstrate a compelling interest-something more than a rational relationship-to justify conditioning altogether the right to run for public office upon payment of a monetary fee. Some fee schemes do, in fact, so condition access to the electorate. The constitutionality of such schemes depends upon the interests alleged by the state to justify imposing such an absolute fee.

Harper and Williams, read together, suggest that the constitutional protections afforded the right to vote require at least some restrictions on the power of the states to limit candidacy.

Consideration of Williams and Jenness together suggests that while the state may not give a virtual ballot monopoly to particular parties, and by analogy to particular candidates, it does have legitimate interests that justify, in some circumstances, restricting access to the electorate altogether and, in other circumstances, giving preferential treatment to large, well-established parties. To some extent the constitutionality of the state's scheme depends upon the criterion by which the state classifies and upon consideration of the extent to which protected interests are being burdened. One must also examine, however, with respect to those schemes that burden only certain routes of access to the electorate, the degree of difficulty different routes to political office require a particular candidate to face.

\section{Qualifying Mechanisms: Of Ends, Means, and Alternatives}

Having examined the constitutional protection accorded the interests of candidates and voters, this analysis must also take into account the states' legitimate interests in restricting access to the electorate. A brief catalogue of the interests advanced by the states to support fee schemes will suffice at this point because the common question raised in recent cases ${ }^{89}$ has been not the legitimacy of the state's asserted interests, but the degree of infringement on protected interests wrought by the mechanism chosen to achieve these ends. Assuming the infringement of fundamental rights and the legitimacy of the state's interests, the question becomes whether excluding nonqualifying, prospective candidates is "necessary to promote a compelling state interest." 90

The district court in Wetherington $v$. Adams ${ }^{21}$ isolated three purposes of the qualifying fees attacked in that case: to insure "serious" political candidates, to accommodate the state's election machinery by limiting the number of candidates, and to provide monetary support to political parties. ${ }^{92}$ An additional purpose, discussed and held not com-

89 See cases cited note 5 supra.

90 Kramer v. Union Free School Dist., 395 U.S. 621, 627 (1969) (emphasis added); see Socialist Workers Party v. Welch, 40 U.S.L.W. 2275 (S.D. Tex. Oct. $27,1971)$.

91309 F. Supp. 318 (N.D. Fla. 1970) (3-judge court).

$92 I d$. at 321 . 
pelling in Carter $v$. Dies, ${ }^{03}$ is to help defray the cost of conducting the particular election. Whether these interests justify a scheme of qualifying fees depends upon the necessity of excluding prospective candidates who cannot pay fees to achieve the particular goal, ${ }^{94}$ the determination of which requires in turn application of the principle that a state's interest in employing a particular means to achieve a particular goal cannot be compelling or necessary if there exists a viable but less burdensome method to reach substantially the same results. ${ }^{95}$

Our examination must be made within a complex framework of variation. Constitutional analysis of fee schemes must take into account the various kinds of classifications that the state's qualification procedure erects. Thus, some prospective candidates will be given name placement on the ballot, while others will either have to rely on write-in votes or be excluded totally from voter consideration. In addition, candidates whose names appear on the ballot are visibly classified: some, endorsed by political parties, will carry the party label onto the ballot, while others will run only as independents.

Recognizing the importance of political endorsement and name placement on the ballot does not reflect condemnation; rather it suggests that analysis must account for the realities of American politics. Thus, because to a great extent American politics is party politics, the great advantage that party endorsement provides must be given candid recognition in constitutional analysis. Similarly, recognizing the importance of the printed name rests on a related, though more general phenomenon-the inherent difficulty in winning as, and voting as part of a movement for, a write-in candidate. Constitutional analysis must not blind itself to these two realities.

The following analysis, accordingly, will treat these three statusesparty candidate, independent, and write-in candidate-as different.

First, those schemes in which payment of a fee is required of every prospective candidate will be considered and compared with other qualifying schemes available to, and already used by many, states. The analysis will then shift to examine those schemes in which payment of a fee is required for name placement on the ballot, but in which a write-in space is provided, to determine whether such an alternative route to office excuses fee requirements. Finally, the analysis will focus upon those fee schemes in which fees are required only of those prospective candidates desiring to run in a party primary to determine whether the presence of alternative routes to name placement on the general ballot not encumbered by fees will save the scheme.

93321 F. Supp. 1358, 1361 (N.D. Tex. 1970) (3-judge court).

94 Kramer v. Union Free School Dist., 395 U.S. 621, 627 (1969).

95 See Wormuth \& Mirkin, The Doctrine of the Reasonable Alternative, 9 UTA L. REv. 254 (1964) ; Developments in the Law-Equal Protection, supra note 36, at 1102 \& n.154; Note, Discriminations Against the Poor and the Fourteenth Amendment, 81 HaRv. L. REv. 435, 442 (1967); cf. Shelton v. Tucker, 364 U.S. 479, 488 (1960); Talley v. California, 362 U.S. 60, 64 (1960). See also Struve, The Less-RestrictiveAlternative Principle and Economic Due Process, 80 HARv. L. REv. 1463 (1967). 


\section{A. Absolute Fee Requirement for Chance to Run for Office}

Thirteen states require that both independent and party primary candidates pay a fee for placement on the ballot. ${ }^{96}$ Of these, eleven provide a write-in mechanism as an alternative to ballot placement in either the general election ${ }^{97}$ or both the general and primary elections; ${ }^{98}$ in two states, payment of a fee is an absolute requirement for office. ${ }^{99}$ Thus, in two states it is clear that the fee is charged for the chance to run for office in any manner. In the other eleven states the fee is charged for name placement on the ballot-the chance to run for office in a particular way. Whether such fee schemes should be permitted to stand under Turner's application of the equal protection clause depends upon the state's interests asserted to justify the imposition of fees.

The state's interest in assuring that only "serious" candidates be permitted to run for public office, while legitimate, in no way justifies the imposition of qualifying fees. First, a candidate's seriousness is certainly not a function of his ability to pay a fee. Clearly, some prospective, serious candidates will be rich and others poor. Thus, not all serious candidates will qualify to run and, indeed, it is probable that some serious candidates will not qualify. ${ }^{100}$ Because a fundamental right is involved, the Constitution simply requires the state to take better aim. ${ }^{101}$

In the second place, the payment of a fee and the sanction of exclusion are unnecessary to promote this interest. A particular means is not necessary for achieving a particular goal if an alternative can achieve the same goal. Thus, if "serious" means having a certain degree of support, a nominating petition requirement furthers this objective at least as well as a fee scheme and, because it is a viable alternative, ${ }^{102}$ makes the fee unnecessary. A nominating petition, containing signatures from a certain percentage of the qualified voters, meets the state's need by screening out frivolous candidates while

96 See Appendix infra.

97 Id. Georgia and Florida are 2 of these states.

$98 \mathrm{Id}$.

99 Id. These states are Hawaii and Ohio. Although Ohio permits write-in votes, write-in candidates must pay a fee. Id. Thus, Ohio, like Hawaii, charges a fee for the chance to run for office. It is questionable whether Ohio can assert any interest sufficient to justify such a write-in fee that contributes to an absolute fee scheme. Assuming that financing the cost of counting write-in votes is legitimate, tax revenues serve this purpose and are less restrictive. See text following note 103 infra.

100 The classification is thus both underinclusive and overinclusive. See Tussman $\&$ tenBroek, supra note 28 , at $352-53$. The overinclusive elements are probably the least defensible since while the class of noncandidates includes poor, nonserious candidates, whom by hypothesis the legislature has the right to exclude, that class also includes poor, serious candidates. See $i d$. 351. The class of noncandidates is also underinclusive because rich, nonserious candidates are permitted to run.

101 See Turner v. Fouche, 396 U.S. 346, 364 (1970); Kramer v. Union Free School Dist., 395 U.S. 621, 632 (1969).

102 It should be noted that 15 states apparently feel that the petition alternative sufficiently promotes their interests to use it exclusively. See Appendix infra. 
making the candidate's access to the ballot a function of his political support. Moreover, requiring a petition does not inhibit political association and expression but, because the candidate and his supporters must go to the public to argue issues, the petition alternative actually encourages valuable political activity.

The state's interest in using a qualifying fee scheme to accommodate its voting machinery presents somewhat different problems. The issue becomes whether the state may restrict the number of names appearing on the ballot to accommodate the machines it already has or, put a different way, whether to save the expense of, perhaps, constructing new machines, the state may constitutionally restrict the size of the ballot on the basis of ability to pay a fee.

First, it is clear that the state does not have an unlimited right to restrict the size of the ballot. ${ }^{103}$ Secondly, assuming that the state can, to some extent, constitutionally limit ballot size, the use of qualifying fees is not compelling nor is the exclusion of nonpaying candidates necessary to promote this interest, since the nominating petition is an equally effective means to achieve the same goal and restricts on a basis that is clearly related to the purpose of candidacy. As far as the state is concerned in having a limited ballot, any requirement that limits the number of candidates should be sufficient. It is clear that the qualifying fee serves this purpose. But the nominating petition serves this purpose equally well and at the same time uses as its criterion the only measure that makes sense in the American political system: the popularity of, and potential votes behind, a political aspirant.

Similarly, as to the state interest in defraying the cost of the particular election, fees and exclusion for nonpayment are not necessary, nor is the interest sufficiently compelling to justify the burdens imposed on voters and candidates. Elections benefit the public in its entirety, and by legitimizing the transfer of power, serve to preserve the political ordering of the lives of the citizenry. Singling out prospective candidates to bear more of this burden than do the average taxpayers is indefensible. Instead, because alternative means are available to achieve the state goal, the qualifying fee cannot be used for this purpose.

Although an absolute fee requirement unconstitutionally burdens protected interests, the nominating petition would be constitutional as an absolute requirement either for running for office in any manner or for name placement on the ballot.

First, a nominating petition effectively achieves many of the state goals that the courts have erroneously found to be supported by the qualifying fee schemes. Reflecting the state's legitimate interest in restricting the size of the ballot to minimize confusion, accommodate voting machinery, and avoid the damage to the voting process that an unlimited ballot might otherwise cause, the nominating petition demands a showing of support as a prerequisite to ballot placement. At the same

103 Cf. Williams v. Rhodes, 393 U.S. 23 (1968), 
time, the nominating petition insures that only "serious," well-supported candidates will gain access in terms of a criterion relevant to American politics-voter support.

Secondly, although a qualifying fee requirement is designed to achieve the same goal, its purpose is effected by means of a monetary exaction that arbitrarily discriminates between rich and poor while burdening constitutional rights. A nominating petition does not necessarily have the same effect. While meeting a petition requirement may involve cost, it does not require payment of money. Thus, although a wealthy candidate can pay for the circulation of his petition, a poor candidate can enlist the aid of his supporters in a campaign for signatures. While it may be argued that since time is money, the poor candidate ought, in theory at least, be able to raise the money for a qualifying fee as easily as he can the time required to obtain signatures, in fact it is more likely that his poor supporters will have the time but not the money to invest in their candidate's campaign.

\section{B. Absolute Fee Requirement for Name Placement on the Ballot}

On the other hand, as to those states that provide a write-in route to the office, for which no fee is required, it would seem that the state is selling name placement on the ballot and not merely the only chance to become an officeholder. In effect, however, selling name placement on the ballot is tantamount to selling the only real chance to win the election, a fact one can verify by consulting common empirical studies of voting patterns. ${ }^{104}$

As a simple matter of fairness, a write-in alternative can never be constitutionally sufficient to justify a fee scheme:

[E]ven where operative, the write-ins are no substitute for a place on the ballot.

To force a candidate to rely on write-ins is to burden him with disability. It makes it more difficult for him to get elected, and for the voters to elect him. ${ }^{105}$

Because of this disability, the election winner's victory cannot be explained in terms of greater popularity. It is necessary to explain his victory in terms of the inherent difficulty of electing a write-in candidate. Moreover, because a write-in candidate's name does not appear

$104 \mathrm{On}$ one level it is clear that it is more difficult for the write-in voter to remember a name and properly fill in his ballot than for another voter to pull a lever beside a printed name. In this regard, it is interesting to note that, at least in federal elections, few write-in votes are cast. Thus, in the 1968 senatorial elections, of 50,693,952 votes cast, only 14,163 were for write-in candidates. Of these, 14,118 came from Alaska. Factual Campaign INFORMation 11 (1970) (compiled by the Senate Library). In the 1968 presidential election, of $73,026,831$ votes cast, only 2,645 were write-ins. Id. 13 . This small number is probably a result of both the mechanical difficulty of casting a write-in ballot and the voter's natural wish to vote for a candidate who, he thinks, has a chance of winning. See J. CORRY \& H. ABraHaM, Elements of Denrocratic Government 292 (4th ed. 1964).

ios Williams v. Rhodes, 393 U.S. 23, 37 (1968) (separate opinion of Douglas, J.). 
on the ballot, it stretches the word to call this provision a viable "alternative" to name placement. ${ }^{106}$ The state simply provides no alternative, in the sense of a sufficient substitute, when it gives the feepaying candidate a place on the ballot and gives the candidate who does not pay the fee nothing but the promise to count his votes.

Because, in effect, a fee scheme conditioning name placement on the ballot upon payment of a fee is functionally equivalent to a scheme that requires all prospective candidates to pay a fee, it should be treated constitutionally as such and struck down, simply by application of Turner to fee requirements.

\section{Fee Requirement for Political Party Label}

The analysis thus far has proceeded on the assumption that the particular qualifying fee scheme requires payment as an absolute requirement either to ballot placement or to the chance to run at all. While thirteen states make fees such an absolute requirement, ${ }^{107}$ another eighteen states require fees only of primary candidates. ${ }^{108}$ Prospective candidates may, thus, gain name placement on the ballot as independents without paying a fee. Any of these eighteen states might argue that although fees are required of some candidates (those who desire to run in a political party primary), there is no absolute bar to name placement on the general ballot, and, thus, the electoral scheme, taken as a whole, provides sufficient access to the electorate. The important issue is, however, whether the state may restrict by means of a monetary fee the opportunity to run in a party primary, regardless of whether the door to independent candidacy is open.

Primaries are, of course, like any other form of state action subject. to the fourteenth amendment's requirement of equal protection. ${ }^{109}$ This subjection does not mean, however, that there are no relevant distinctions between the primary and the general election. Thus, it can be argued that the equal protection clause invalidates state action that

100 In addition, some states require write-in candidates to pay the same fee as other candidates. See, e.g., OHIo REv. CODE ANN. \$\$3513.10, 26.1 (Page Supp. 1970). In such cases, of course, the write-in cannot be considered an alternative to paying the fee for ballot placement.

107 See Appendix infra.

$108 \mathrm{Id}$. Thus, 31 states require fees of some kind. It is interesting to note that while 18 states require fees only of primary candidates, no state requires fees only of independents. Obviously, these 18 states are charging for the opportunity to run in the primary- the chance to win party endorsement and carry the party label on the general ballot. It should also be noted that Kansas, Michigan, Oklahoma, and New Hampshire are not included in this group of states because they do not require the payment of a fee but merely provide a fee mechanism as an alternative to other qualification requirements. See Appendix infra.

109 See Smith v. Allwright, 321 U.S. 649, 664 (1944):

When primaries become a part of the machinery for choosing officials, state and national, .... the same tests to determine the character of discrimination or abridgement should be applied to the primary as are applied to the general election. 
places a price on both the primary and general election ballot precisely because such a fee scheme effectively bars from running at all candidates who do not pay. ${ }^{110}$ This absolute bar exists because any candidate whose name appears on the general ballot will have had to pay a fee, and not because of the primary fee alone. Moreover, since the primary is only a preliminary step to placement on the general ballot, being barred from the primary ballot does not foreclose the chance to run for election and win as an independent. And, since the only reason to apply the equal protection clause in the fee context is to protect the rights of candidates and voters, that clause should not apply when the right to run, and the right to vote, may be exercised in the general election. Moreover, it can be argued that additional state interests distinguish further the primary from the general election.

The fallacies of this reasoning, however, are apparent from the facts it assumes. Clearly, the rights of candidates and voters are not always adequately protected by an open candidacy provision. First, the primary is not simply a preliminary step to the general election ballot. Instead, in a country whose politics are organized along party lines, ${ }^{111}$ the primary is an integral part of the entire electoral process. Because of universal suffrage and the great variety of diverse opinions held by members of the electorate, parties serve the essential function of organizing voters into majorities behind candidates and their programs. ${ }^{112}$ This function of organization is also essential to the efficiency, indeed management, of government because it leads to the concentration of power that makes possible the carrying out of policy. ${ }^{113}$ The primary is part and parcel of this entire process because through it the electorate determines who the party candidates will be.

Secondly, with party nomination come many advantages. On one level, the party's standard bearer derives advantage from the party's organization, its funds, its workers, its campaign literature,

110 Under this reasoning the result would be similar in a scheme that requires fees only of those whose names appear on the general ballot. (No state does this.) Thus, under such a scheme although primary candidates will not as such be required to pay, the primary winner, to get his name on the general ballot, will have to pay the fee. Such a scheme means that one who cannot pay the fee must enter the primary, since by hypothesis only in that election is no fee required. But, if he wins, the candidate will have to pay a general election fee to get his name on the general ballot. Either he cannot and does not pay it, or the party must pay it for him. Thus, he is in the same situation as persons in a state that requires fees of both primary and independent candidates. Under the earlier analysis, it is unconstitutional for the state to place an absolute monetary bar in front of the candidate, which is exactly what a general fee such as this one does. Moreover, the situation does not change merely because here the candidate may get into the party and because the party can pay the fee for him. It may be unconstitutional for the state to leave him only the alternative of joining the party to get on the ballot-perhaps this infringes upon his right to freedom of association.

111 See A. Sindler, Political Parties in the United States (1966) ; S. Lipset, Political Man 303-31 (Anchor ed. 1963).

112 See J. Corry \& H. Abraham, supra note 104, at 293.

113 Id. 291. 
and its name.114 On another level, a party candidate does in fact have the best chance of winning the election because he is known as the party candidate. ${ }^{115}$ In some states the particular primary may be the only election worth running or voting in since the party nominee will win the election. ${ }^{116}$ In other states, more closely approximating the ideal of two-party theory, the chances are still high that one of the two major party candidates will win, ${ }^{117}$ although the election of a particular party's candidate is not assured.

The question, then, is on what basis may the state distribute this advantage? In those states in which a particular party candidate is assured of election, the right to vote effectively, ${ }^{118}$ the right to associate, ${ }^{119}$ and the right not to be barred as a candidate on an unconstitutional basis can only be protected by invalidating primary fees regardless of the presence of an independent candidacy provision, because the real determination of who the officeholder will be is made at the primary and not the general election. In other states, the great advantage that party nomination provides, not in terms of assuring election, but in terms of giving party candidates a significant edge over independents, also militates in favor of requiring the state to show compelling reasons to

114 Id. 296; see D. Balmer, Financing State Senate Campaigns: MultNoman County, ORegon, 1964, at 11-12 (1964). The state sometimes becomes even more directly involved, as when it makes available to party candidates public patronage employees for campaigning purposes. See Shakman v. Democratic Organization of Cook County, 435 F.2d 267 (7th Cir. 1970).

115 See generally J. CORRY \& H. ABRAFAM, supra note 104, at 291-93.

116 If such is the case, then, in that particular state, independency is no alternative at all. See C. Ewing, Primary Elections in the South-A Study in UnIParty PoLITICs (1953). This study indicates that in the relevant general elections no real decisions were made, and that in party primaries the voters were actually selecting public officials. In such a situation, the citizen cannot forego the privilege of party membership and still remain an active voter. Thus, the only chance he will have to vote effectively is in the primary.

In his concurring opinion to Carter v. Dies, 321 F. Supp. 1358, 1363 (N.D. Tex. 1970), Judge Thornberry analyzed a primary fee, taking these factors into account. Because the fee was an absolute requirement for placement on the primary ballot and because party nomination is, at least in Texas, "tantamount to election," he viewed the fee as a direct burden on the right to vote effectively. Id. at 1363-64. Moreover, it is apparent that he was not referring to the right to vote effectively in the primary, but the right to have an effective vote in determining who will win the election.

117 Although it is difficult to prove from available statistical information that independents and minor party candidates have little chance to win elections, in the past they have not been very successful. Even in federal elections in which the uniparty politics of some states is beginning to show signs of crumbling, see M. JeWeil, Legislative Representation IN the Contemporary South 109, 123 (1967), it is apparent that either Republicans or Democrats normally win. For instance, there has never been an independent or minor party president. See CoNgressional Quarterly Special Report-Presidential Candidates From 1788-1964 (1964). Moreover, very few independent or minor party members have sat in Congress. See Factual CaAsargn Inforamation 7 (1970) (compiled by the Senate Library). Similarly all governors are either Democrats or Republicans. Id. 15.

118 See Carter v. Dies, 321 F. Supp. 1358 (N.D. Tex. 1970), in which the court based its holding that the general fee involved violated the equal protection clause on the rights of voters and not candidates, and, in fact, on this basis distinguished Wetherington. Id. at 1362-63.

119 See id. at 1363 (Thornberry, J., concurring). 
justify the necessity of primary fees. ${ }^{120}$ This does not mean that candidates have an absolute constitutional right to access to a political primary; rather, because exclusion from the party primary denies to associational groups, voters, and candidates a real shot at election, candidates from the class of those "injured" by fee requirements do have a federal constitutional right to be considered by the voters for the normal, and in many instances the only realistic, chance to reach public office without the burden of invidiously discriminatory disqualifications. ${ }^{121}$

Again the state can show no compelling interest. Assuming that financial support of political parties is a legitimate state interest, fund raising can be accomplished by less restrictive means. ${ }^{122}$ Thus, excluding nonpaying, prospective candidates is not necessary to fulfill the state goal. ${ }^{123}$ Similarly, all other valid state interests can be effectively served by less restrictive means. Accommodating voting machines and permitting voters a narrower than infinite choice of candidates is well served by any method that does not permit every candidate ballot placement. A nominating petition requirement would serve not only those state interests, but would also demonstrate the candidate's support. While courts should tread lightly when asked to tell the legislature how to spend its money, ${ }^{124}$ it is also clear that the legislature, having made its choice, should be required to choose means consistent with the fourteenth amendment. A primary fee scheme, thus, fares little better under equal protection analysis than a fee scheme that absolutely bars nonpaying candidates.

\section{ConCLUSION}

This Comment has analyzed the constitutionality of three kinds of qualifying fee schemes: those that require fees of all prospective candidates, regardless of the particular route to office they have chosen; those that condition name placement on the ballot upon payment of a fee; and those that require fees only of those who desire to run in a party primary. Absolute fee schemes are unconstitutional because, in effect, they require a fee for the chance to run for office. Under recent Supreme Court cases, such a fee cannot be permitted to stand. The other fee schemes, on the other hand, require fees not for the opportunity to run for public office, but for the opportunity to seek that office along a particular route that the state has provided-with name placement on the ballot or through the primary system. Because in each situation the

120 See Williams v. Rhodes, 393 U.S. 23, 37 (1968) (Douglas, J., concurring); cf. Spillers v. Slaughter, 325 F. Supp. 550 (M.D. Fla. 1971).

121 See text accompanying notes 55-88 supra.

122 See Carter v. Dies, 321 F. Supp. 1358, 1361-62 (N.D. Tex. 1970).

123 See Appendix infra.

124 See Note, Discriminations Against the Poor and the Fourteenth Antendment, 81 HaRv. I. REv. 435, 440-41 (1967). 
state is providing a route of great advantage in terms of the chance to win the election, and because each scheme affects the constitutionally protected interests of voters and associations as well as the interests of individual candidates and the overall political system, they, too, must fall.

These fee schemes fall, however, not because of their restrictive nature, but because of the nature of the criterion by which they restrict. Although the state has legitimate interests in restricting access to the ballot and to the electorate, when protected interests are burdened in the context of the political process, the state must be prohibited from making grossly overinclusive classifications among its citizens. Thus, fee schemes must be struck down. In this context courts, although reluctant to impose their views upon state legislatures, must, at least, require the state to choose the least restrictive means to achieve a particular legitimate end. Only in this way can the interests of all-voters, candidates, parties, and the state-be adequately protected. 


\section{APPENDIX}

The following table describes the election procedures of the fifty states with respect to fee and petition requirements and the availability of write-in provisions. The data on which the table and the footnotes are based generally relate to major offices: President, United States Senator, United States Representative, Governor, State Senator, and State Representative.

The table is first divided into primary and general election categories. Primary requirements apply to prospective candidates for party nomination, while general election requirements apply to independents. In addition, some states, as noted in the footnotes where relevant, provide that minor parties may nominate by convention. These nominated candidates gain name placement on the general ballot without having run in a primary, and in many cases must meet the independent requirements.

Under both the primary and general election categories the table indicates whether there is a fee requirement, a petition requirement, or both. Each requirement is described in terms of whether it is an absolute requirement (abs.) for gaining placement on that particular ballot or merely an alternative means (alt.) for gaining such placement. Thus, an $X$ under "general fee absolute" means that to gain placement on the general ballot, an independent must pay a fee.

To determine whether a fee or petition is required for name placement on the general ballot for both party and independent candidates, the reader must look under both the primary and general election categories. Every state automatically provides name placement on the general ballot for the primary winner; thus, he does not have to meet any additional requirement. But, if primary candidates must pay a primary fee and independents must pay a general fee, then from the prospective candidate's point of view, in order to gain name placement on the general ballot, he must pay a fee, whether payment be specifically to enter the primary or to enter the general election. In this sense, everyone whose name appears on the general ballot had to have paid a fee at one time or another.

The write-in categories show whether the state permits voters in the particular election to vote for candidates other than those listed on the printed ballot; from a prospective candidate's viewpoint, a write-in provision means that for the particular election, he does not have to gain name placement on the ballot to run for election. By looking at the primary, general, and write-in categories, the reader can determine 
whether a particular requirement is an absolute prerequisite for running for office. Thus, if both primary and independent candidates must pay a fee and there is no write-in provision, the fee is then an absolute requirement for the chance to run for office in the sense that no one can be elected without paying a fee. On the other hand, the presence of a write-in provision would mean that payment of a fee is not an absolute requirement for the opportunity to run for office. 
Table of Election ReQuirements (by State)

$\begin{array}{clccc}\text { Primary } & \text { Primary } & \text { General } & \text { General } & \\ \text { Fee } & \text { Petition } & \text { Fee } & \text { Petition } & \text { Write-in }\end{array}$

Abs. Alt. Abs. Alt. Abs. Alt. Abs. Alt. Primary General

\begin{tabular}{|c|c|c|c|c|c|c|}
\hline Alabama 1 & $\mathrm{X}$ & & & $\mathrm{X}$ & & $\mathrm{X}$ \\
\hline Alaska 2 & $\mathrm{X}$ & & & $\mathrm{X}$ & & $\mathrm{X}$ \\
\hline Arizona 3 & & $\mathrm{X}$ & & $\mathrm{X}$ & $\mathrm{X}$ & $\mathrm{x}$ \\
\hline Arkansas 4 & $\mathrm{X}$ & & $\mathrm{X}$ & $\mathrm{X}$ & $x$ & $\mathrm{X}$ \\
\hline California 5 & $\mathrm{X}$ & & & $\mathrm{x}$ & $\mathrm{X}$ & $\mathrm{x}$ \\
\hline Colorado 6 & & $\mathrm{X}$ & & $\mathrm{X}$ & $\mathrm{X}$ & $x$ \\
\hline Connecticut 7 & $\mathrm{X}$ & $\mathrm{x}$ & & $\mathrm{x}$ & & $\mathrm{X}$ \\
\hline Delaware ${ }^{8}$ & $\mathrm{X}$ & & & & & $x$ \\
\hline Florida $^{9}$ & $\mathrm{X}$ & & $X$ & $\mathrm{X}$ & & $x$ \\
\hline Georgia 10 & $\mathrm{x}$ & & $\mathrm{X}$ & $\mathrm{x}$ & & $x$ \\
\hline Hawaii 11 & $\mathrm{x}$ & $\mathrm{x}$ & $X$ & $\mathrm{X}$ & & \\
\hline Idaho 12 & $\mathrm{X}$ & $\mathrm{x}$ & $\mathrm{x}$ & $\mathrm{X}$ & $\mathrm{X}$ & $x$ \\
\hline Illinois 13 & & $\mathrm{x}$ & & $x$ & $\mathrm{X}$ & $\mathrm{X}$ \\
\hline Indiana 14 & & & & $\mathrm{X}$ & & $\mathrm{x}$ \\
\hline Iowa 15 & & $\mathrm{X}$ & & $\mathrm{X}$ & $\mathrm{X}$ & $\mathrm{X}$ \\
\hline Kansas 18 & $X$ & $\mathrm{X}$ & & $\mathrm{X}$ & & $\mathrm{X}$ \\
\hline Kentucky ${ }^{17}$ & $\mathrm{X}$ & $\mathrm{x}$ & & $X$ & & $\mathrm{X}$ \\
\hline Louisiana 18 & $\mathrm{x}$ & & & $\mathrm{X}$ & & $\mathrm{X}$ \\
\hline Maine 19 & & $\mathrm{X}$ & & $\mathrm{x}$ & $\mathrm{x}$ & $\mathrm{x}$ \\
\hline Maryland 20 & $\mathrm{X}$ & & & $\mathrm{x}$ & & $\mathrm{X}$ \\
\hline Massachusetts 21 & & $\mathrm{X}$ & & $\mathrm{X}$ & $\mathrm{X}$ & $\mathrm{X}$ \\
\hline Michigan 22 & $\mathrm{X}$ & $\mathrm{x}$ & & $x$ & $\mathrm{X}$ & $\mathrm{X}$ \\
\hline Minnesota 23 & $\mathrm{x}$ & & & $\mathrm{X}$ & & $\mathrm{X}$ \\
\hline Mississippi 24 & $\mathrm{X}$ & & & & & $\mathrm{X}$ \\
\hline Missouri 25 & $\mathrm{X}$ & & & $\mathrm{X}$ & & $\mathrm{x}$ \\
\hline
\end{tabular}


Table of Election Requirenients (by State)

Primary Primary General General

Fee Petition Fee Petition Write-in

Abs. Alt. Abs. Alt. Abs. Alt. Abs. Alt. Primary General

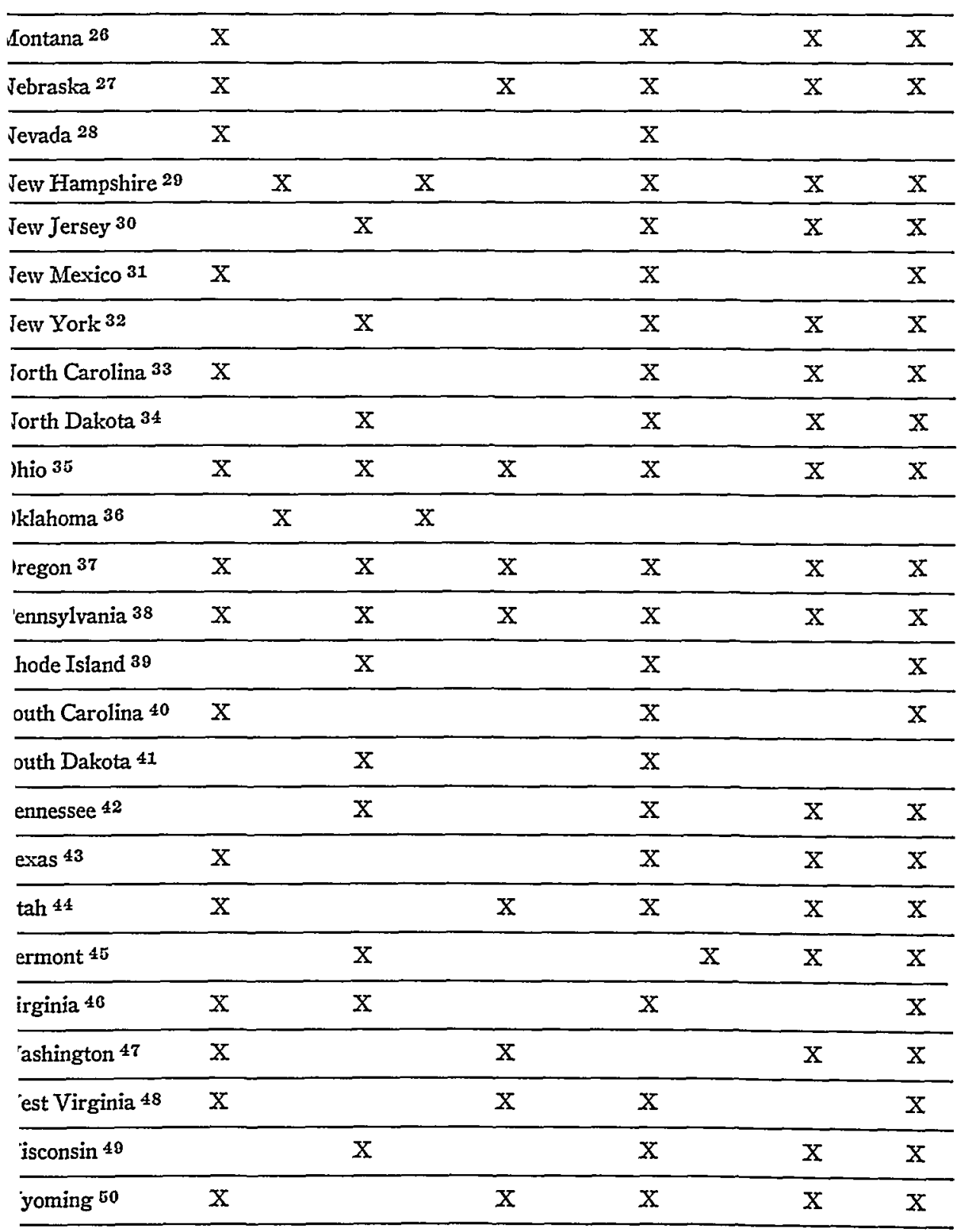


1 ALA. CODE tit. 17, $\$ 348$ (party assessment), 145 (general petition), 162 (general write-in) (1959). Like some other states, Alabama does not set fees by statute, but instead delegates to the parties the power to charge fees. Such fees are here called "assessments."

2 Alaska Stat. $\$ \$ 15.25 .050$ (primary fee), .140-.190 (general petition). 15.030 (5) (general write-in) (1971).

3 Artz. Rev. Stat. AnN. $\$ \$ 16-303$ to -305 (primary petition), -601 (general petition), $-571 \mathrm{C}$ (primary write-in), -844G (general write-in) (Supp. 1971).

4 Ark. Stat. ANn. \$\$3-109 (party assessment), -120 (e), (f) (general fee), -105 (c) (general petition), -114 (primary write-in), $-613(\mathrm{k})$ (general write-in) (Supp. 1969).

5 Cal. Elections Code $\$ \S 6552,6554$ (primary fees) (West Supp. 1971), 6800, 6831 (general petition), 6555 (primary write-in), 14,412 (general write-in) (West 1961).

6 Colo. Rev. Stat. ANs. $\$ \$ 49-6-7$ (primary petition), $-7-1$ (general petition), -8-6(5) (primary write-in), -11-7(7) (general write-in) (1963).

7 Conn. Gen. Stat. Ann. $\$ 9-400$ (primary petition \& fee) (Supp. 1971) ; Public Act No. 806 (Conn. Legislative Service 1081) (general petition) (1971) ; CoNN. Gen. Stat. ANN. \$ 9-265 (general write-in) (Supp. 1971). Although party-endorsed candidates automatically win primary ballot placement, id. $\$ \$ 9-382,-416$ (1967), this table describes the primary fee and petition requirements as absolutes. This is true as well with the general ballot. Because the party endorses only 1 candidate, calling these requirements absolute more accurately reflects the situation of prospective candidates.

8 DEL. CODE ANN. tit. 15, $\$ 3104$ (party assessment), 4502 (general write-in) (Supp. 1970). In Delaware apparently the only way to get on the general ballot is through the primary; thus, fees are an absolute requirement both for running in the primary and for running in the general election. The fee which the party may set is limited to a maximum of $3 \%$ of the total salary for the entire term of office. $I d$. $\$ 3104$. Candidates for the United States Senate would have to pay a maximum of $\$ 7,650$.

9 Fla. Stat. Ann. $\$ \$ 99.092$ (primary fee \& party assessment), $152, .153$ (general petition \& fee), 101.011 (2) (general write-in) (Supp. 1971). The filing fee for both primary candidates and independents is $3 \%$ of the annual salary of the office sought; in addition, the party may assess each primary candidate an additional $2 \%$ of the annual salary. Moreover, for checking signatures on petitions, Florida charges $10 \phi$ per name. Since the petition requirement for statewide offices is $5 \%$ of the state's registered voters, $i d$. $\S 99.152$, and since Florida has approximately $2,765,000$ registered voters, see InFORMatron Please AlMANaC 1971, at 127 (1970), each independent will be required to pay $\$ 13,825$ for having signatures checked. The total amount that a candidate for the United States Senate, for instance, will have to pay both in fees and in having his petition checked is, therefore, $\$ 15,100$.

10 GA. CoDE ANN. $\$ \$ 34-1013$ (primary \& general fee), -1010 (general petition), -1103 (b) (general write-in) (1970).

11 HawaII Rev. Laws $\$ \$ 12-6$ (primary fee), -3, -5 (primary petition) (Supp. 1970). Sections 12-2 and 12-41 require independents, subject to the same fee and petition requirements, to run in a nonpartisan primary.

12 IDAFO CODE $\$ 34-604$ to $-615,-701$ (primary fee \& petition), -604 to -615 (general fee \& petition), -702 (primary write-in), -906 (general write-in) (Supp. 1970). Independents must file for a party primary. Id. \$34-703. Primary write-in candidates must pay a fee. $I d$. $\$ 34-702$.

13 Il.. ANn. STAT. ch. 46, \$\$7-10, 8-8 (primary petition), 10-3 (general petition), 7-46 (primary write-in) (Smith-Hurd Supp. 1970), 24-14, 24-16 (general write-in) (Smith-Hurd 1964); see Sanner v. Patton, 155 Ill. 553, 40 N.E. 290 (1895) (state constitutional right to write-in candidate's name).

14 IND. ANN. STAT. \$\$29-3801 (general petition) (Supp. 1971), -5023 (general write-in) (1969). Primary petitions are required of Presidential candidates. Id. $\$ 29-3619$. For other offices nominations are made either by primary or convention; candidates face no requirements.

15 Iowa CoDE $\$ \S 43.11$ to 22 (primary petition) (Supp. 1971), 45.1 (general petition), 43.66 (primary write-in) (1949), 49.99 (general write-in) (Supp. 1971).

16 Kan. STAT. ANN. $\$ \$ 25-206$ (primary fee), -205 (primary petition), -303 (general petition), -602 (general write-in) (Supp. 1969). A primary write-in is provided only if no other candidate has filed a petition or paid a fee. Id. \$25-213. 
$17 \mathrm{Ky}$. Rev. Stat. ANN. $\$ 119.050$ (primary petition), .250 (primary fee), 118.080 (general petition), 118.280 (general write-in) (1969). For consistency, although $\$ 119.050$ requires only affidavits of two electors, it is here considered to be a nominal petition requirement. The filing fee is only $\$ 1$. The general petition is an alternative since $\$ 118.090$ permits minor party candidates to enter the general election without running in the primary or filing a petition.

18 LA. Rev. Stax. ANN. \$\$18:310, :314 (primary fee), :624 (general petition), :732 (general write-in) (1969). Louisiana actually is in a class unto itself, requiring a $\$ 500$ fee before the election if a candidate wishes his general election write-in votes counted. Id. $\$ 18: 732$. In terms of the textual analysis this would probably fit best the case where no write-in is available; the general election is not fee regulated and the primary-fee-only analysis seems appropriate.

10 ME. Rev. STAT. ANN. tit. 21, \$\$ 441 (primary petition), 491 (general petition), 701 (primary write-in), 702 (general write-in) (1964).

$20 \mathrm{MD}$. ANs. CoDE art. 33, §\$4A-6 (primary fee), 7-1 (general petition), 14-1, 17-5 (general write-in) (1971).

21 Mass. ANn. LAws ch. $53, \S \S 44$ (primary petition), 6 (general petition), 3 (primary write-in), ch. 54, $\$ 42$ (general write-in) (1971). The primary petition is an alternative because ballot placement for state-wide office can be gained by receiving at least $20 \%$ of the vote at a state convention.

22 MICH. CoMrp. Laws ANN. $\$ \$ 168.550$ (primary fee), .542 (primary petition), .685 (general petition), .572 (primary write-in), .706 (general write-in) (1967). The primary fee and petition are alternatives for state senators and representatives. This alternative of paying a fee is not open to state executive offices, United States Congressmen, and United States Senators. For them the petition is an absolute requirement.

23 MINN. Stat. ANN. $\$ 202.05$ (primary fee) (Supp. 1971), 09 (general petition), 203.51, 204.10 (general write-in) (1962).

24 Miss. Code ANN. $\$ \$ 3120$ (primary fee) (Supp. 1971), 3269 (general write-in) (1957). Apparently only through a primary can anyone have his name printed on the ballot. Compare Allen v. State Bd. of Elec., 393 U.S. 544 (1969) (holding MIss. CoDE ANN. $\$ 3260$ could not be amended to raise number of signatures required on petition unless in compliance with Voting Rights Act of 1965), with Miss. CoDE ANN. $\$ 3260$ (Supp. 1971) (deleting nominating petition alternative).

25 Mo. ANN. Stat. $\$ \$ 120.350$ (primary fee) (Supp. 1970), .180 (general petition), 121.110 (general write-in) (1966).

${ }^{26}$ Mont. Rev. Codes ANN. \$\$23-3304 (primary fee), -3318 (general petition), -3304 (primary write-in), -3606(4) (general write-in) (Supp. 1971). The general write-in is not available when voting machines will not accommodate it, id. \$23-3805 (1), but is available when electronic voting systems are used. Id. \$23-3904(4).

27 Neb. Rev. Stat. $\$ \$ 32-513$ (primary fee), -504 (general petition \& fee), -428 (primary write-in), -428 (general write-in) (1968).

28 NEv. REv. Stat. $\$ \$ 293.177, .193$ (primary fee), .200 (general petition) (1963). 29 N.H. ReV. STAT. ANN. $\$ \$ 56: 14$ (primary fee), :15, :18 (primary petition), :65, :67 (general petition), :47 (primary write-in), 59:59 (general write-in) (1971). 30 N.J. Star. ANN. \$\$19:23-5 (primary petition), :13-1 (general petition), :23-16, -25 (primary write-in), :15-28 (general write-in) (1964).

31 N.M. Stat. ANN. \$\$ 3-8-26 (primary fee), -8-2 (1970), as anended, .(Supp. 1971), -8-3 (general petition), -12-36 (general write-in) (1970).

32 N.Y. ElECTION LAW $\$ 134$ (primary petition) (McKinney 1964), 138 (general petition) (McKinney Supp. 1971), 212 (primary \& general write-in) (McKinney 1964).

33 N.C. Gen. Stat. $\$ \$ 163-120$ (primary fee), -152 (general petition), $-175(3)$ (primary \& general write-in) (1964).

34 N.D. CENT. CODE $\$ \$ 16-04-02$ (primary petition) (1960), -03-02 (general petition) (Supp. 1971), -04-28 (primary write-in), -12-06 (general write-in) (1960).

35 OHIO REv. CODE ANN. $\$ \$ 3513.10$ (primary fee), .05 (primary petition), .26.1 (general fee), 25.7, .25.8 (general petition) (Page Supp. 1970), .23 (primary writein) (1960), .04.1 (general write-in) (Supp. 1970). In Ohio those who desire to run as write-in candidates must also pay a fee. Id. $\$ 3513.10$.

36 Orla. Stat. Ann. tit. 26, $\$ 161$ (primary fee or petition) (Supp. 1971). Candidates must either present a petition or submit a fee, which the candidate forfeits if his performance in the election is below a given standard. Id. The fee is $\$ 1500$ for gubernatorial candidates and $\$ 200$ for statewide offices. $I d$. 
37 ORE. REV. STAT. $\$ \$ 249.271$ (primary fee), .020(1), .041(1) (primary petition), .271 (general fee), .710, .740 (general petition), .354(4) (primary write-in), 250.110 (4) (general write-in) (1969).

38 Pa. Stat. AnN. tit. 25, $\$ \$ 2873$ (primary fee), 2867, 2872 (primary petition), 2914 (general fee), 2911 (general petition), 2962(b) (primary write-in), 2963 (e) (general write-in) (1963).

39 R.I. GEN. LAwS ANN. $\$ 17-14-7$ (primary petition), $-16-1$ to -3 (general petition), $-19-31$ (general write-in) (1970).

40 S.C. CoDE ANN. $\$ \$ 23-400.74$ (primary fee), .16 (general petition), .17 (general write-in) (Supp. 1970).

41 S.D. Compred Laws ANN. $\S \S 12-6-4$ (Supp. 1971), $-6-5$ to $-6-8$ (primary petition), $-7-1$ to $-7-4$ (general petition) (1967). Certain minor party nominations may be made by convention. Id. $\$ 12-5-21$.

42 TENN. CODE ANN. $\$ \S 2-811,-812$ (primary petition), -1206 (general petition), -1207 (general \& primary write-in) (1971 Repl. Vol.).

43 Tex. Election Code arts. 13.07a, .08a, .15, .16 (primary fee and assessment), (Supp. 1971), .50 (general petition) (1967), .09 (primary write-in), 6.05(3), .06 (general write-in) (Supp. 1971). Only prospective candidates who run in major party primaries must pay a fee. Smaller parties are permitted to nominate by convention, and thus minor party candidates do not have to pay a fee. Id. arts. 13.45, .47 , .47a (Supp. 1971). The primary write-in is illusory since it only permits write-in votes for certain party offices. Id. art. 13.09 .

44 UTAF CODE ANN. \$§20-3-14 (primary \& general fee), -3-38 (general petition), $-3-11,-3-20$ (primary write-in), $-7-5$ (general write-in) (1953). Only the 2 candidates receiving the largest number of votes at a party convention are eligible for name placement on the primary ballot, and if one candidate receives $70 \%$ of the convention vote, he becomes the party's nominee and no primary election is held for that office. Id. \$20-4-9 (Supp. 1971).

45 VT. STAT. ANN. tit. 17, $\$ 334-37$ (primary petition), 573 (general petition), 362,384 (primary write-in), 801, 1043 (general write-in) (1968). The general petition requirement applies only to independents, since minor party candidates may gain general ballot placement by convention nomination. Id. $\$ \$ 571-75$.

46 VA. CODE ANN. $\$ \$ 24.1-198$ (primary fee), -185 (primary petition), -168 (general petition), -217 (general write-in) (Supp. 1971).

47 WASH. REv. Code ANN. $\$ \$ 29.18 .050$ (primary fee), .24.070 (minor party fee), .51 .170 (primary \& general write-in) (1965). Washington does not explicitly provide a route to name placement for independents. Although prospective candidates may enter a major party primary and, thereby, attempt to gain general election ballot placement, minor parties nominate by convention. Id. $\$ 29.24 .020$. These candidates must also pay a fee. Id. $\$ 29.24 .070$. Thus, everyone whose name appears on the general ballot will have had to pay a fee. Minor party nomination must be evidenced by a certificate of nomination issued by the minor party convention. Id. $\$ 29.24 .040$.

48 W. VA. CoDE ANN. $\$ \$ 3-5-8$ (primary fee), -5-23 (general fee \& petition), -6-5 (general write-in) (1971). The general petition is not quite absolute since minor party candidates nominated by convention and not by primary may gain general ballot placement by paying the fee. Id. $\$ 3-5-22,-8$. Independents must pay a fee and submit a petition to gain general ballot placement. $I d$. §3-5-23.

49 WIS. STAT. ANN. $\$ \$ 8.15$ (primary petition), 20 (general petition), 16 (primary write-in), 5.64(1) (a) (general write-in) (1967).

50 Wyo. Stat. ANN. $\$ \$ 22-118.16$ (primary fee), .10, .11 (general petition), .13 (general fee), .21 (primary write-in), .83 (general write-in) (Supp. 1971). The general write-in provision does not apply to candidates for state legislature. Id. $\S 22-118.83$. 